\title{
DAMPAK PERLAKUAN PERATURAN PEMERINTAH NOMOR 46 TAHUN 2013 ATAS PAJAK PENGHASILAN PADA UMKM DI GRESIK
}

\author{
Faiqotul Ilmia \\ Sri Andriani
}

Fakultas Ekonomi, Universitas Islam Negeri Maulana Malik Ibrahim Malang

Jl. Gajayana 50 Malang Telp/Fax. 0341-558881

email: sriandrianiuin@gmail.com/No Telepon 081333689915

Abstract

In achieving the desired development by Indonesia, the government requires revenue from the State Tax Revenue and Non-Tax Revenues. One of the efforts undertaken by the Directorate General of Taxation (DGT) is enacted Government Regulation No. 46 of 2013, the tax base used is the gross turnover of each month at $1 \%$ final income tax rates. The emergence of these regulations is to provide convenience for taxpayers in determining the amount of income tax payable, but enactment of these rules in the middle of giving trouble for taxpayers in the calculation, depositing and reporting taxes for the year 2013. Purpose of this study was to determine the impact of treatment of PP 46 of 2013 on income tax on Micro, Small and Medium Enterprises (SMEs) in Gresik skull cap industry. This study used a qualitative descriptive approach with the aim of obtaining a picture of the object that is easily observed in the form of words on the focus of research on the impact of the enactment of Regulation 46 of 2013. The 3 (three) object of research is no skull cap Industry SMEs in Gresik. Data analysis aims to simplify the data processed, making it easy to read and interpret. Data were collected by means of observation, interviews, documentation. Analysis of the data through three stages: data reduction, data display, and conclusion. The results showed that the enactment of Regulation 46 of 2013 not only creates difficulties in terms of computation, depositing and reporting just as effective mid-year, but still there who do not know the regulations in terms of both has been the enactment of these regulations 
and in terms of the calculation mechanism. As for other effects of the government's enactment of legislation, namely the amount of income tax payable is higher than the income tax calculations using norm bookkeeping or net income.

Keywords: government regulation, income tax, PP No. 46 tahun 2013

Abstrak

Dalam mencapai pembangunan yang diinginkan oleh Indonesia, pemerintah membutuhkan pendapatan dari Pajak Pendapatan Negara dan Penerimaan Negara Bukan Pajak. Salah satu upaya yang dilakukan oleh Direktorat Jenderal Pajak (DJP) diundangkan Peraturan Pemerintah Nomor 46 tahun 2013, basis pajak yang digunakan adalah peredaran bruto setiap bulan sebesar $1 \%$ tarif pajak penghasilan final. Munculnya peraturan ini adalah untuk memberikan kemudahan bagi wajib pajak dalam menentukan jumlah pajak penghasilan terutang, tetapi diberlakukannya aturan ini di tengah-tengah memberikan masalah bagi wajib pajak dalam perhitungan, penyetoran dan pelaporan pajak untuk tahun 2013. Tujuan penelitian ini adalah untuk menentukan dampak dari pengobatan PP 46 tahun 2013 tentang pajak penghasilan atas Mikro, Kecil dan Menengah (UKM) di Gresik tengkorak industri topi. Penelitian ini menggunakan pendekatan deskriptif kualitatif dengan tujuan memperoleh gambaran dari objek yang mudah diamati dalam bentuk kata-kata pada fokus penelitian mengenai dampak dari diberlakukannya Peraturan 46 dari 2013. 3 (tiga) obyek penelitian ada songkok UKM Industri di Gresik. Analisis data bertujuan untuk menyederhanakan data diolah, sehingga mudah untuk membaca dan menafsirkan. Data dikumpulkan dengan cara observasi, wawancara, dokumentasi. Analisis data melalui tiga tahap: reduksi data, display data, dan kesimpulan. Hasil penelitian menunjukkan bahwa berlakunya Peraturan 46 tahun 2013 tidak hanya menimbulkan kesulitan dalam hal perhitungan, penyetoran dan pelaporan tahun pertengahan sama efektif, tapi masih ada yang belum tahu peraturan baik dari segi telah diberlakukannya peraturan ini dan dalam hal mekanisme perhitungan. Adapun efek lain dari diberlakukannya pemerintah dari undang-undang, yaitu dengan jumlah hutang pajak penghasilan lebih tinggi dari perhitungan pajak penghasilan dan norma pembukuan atau laba bersih.

Kata kunci: regulasi pemerintah, pajak penghasilan, PP N. 46 tahun 2013

\section{PENDAHULUAN}

Pembangunan merupakan suatu proses kegiatan yang dilakukan oleh pemerintah dalam rangka mengembangkan dan mengadakan perubahan ke arah yang lebih baik. Pembangunan yang ingin dicapai oleh bangsa Indonesia adalah mewujudkan masyarakat yang adil dan makmur. Untuk bisa mencapainya pemerintah 
membutuhkan pendapatan Negara yang diperoleh dari 2 (dua) sumber yaitu Penerimaan Pajak dan Penerimaan Negara Bukan Pajak (PNBP) seperti penerimaan dari sumber daya alam, setoran laba dari Badan Usaha Milik Negara (BUMN). Penerimaan pajak merupakan sumber utama pendapatan Negara, hampir 78\% (tujuh puluh delapan persen) pendapatan Negara diterima dari pajak dan 70\% (tujuh puluh persen) penerimaan pajak mendanai belanja Negara. Oleh karena itu, Negara mengandalkan penerimaan pajak sebagai penopang APBN yang digunakan untuk membiayai pelayanan publik, seperti jalan, jembatan dan fasilitas umum lainnya.

Besar kecilnya penerimaan pajak ditentukan oleh kesadaran masyarakat baik Wajib Pajak orang pribadi, badan, dan BUT untuk melaksanakan kewajiban perpajakannya, salah satu jenis penerimaan pajak yaitu pajak penghasilan. Pajak penghasilan merupakan pajak yang dibebankan pada penghasilan kepada Wajib Pajak baik orang pribadi maupun badan. Untuk bisa menentukan besarnya Pajak Penghasilan (PPh), Wajib Pajak terlebih dahulu harus menentukan dasar pengenaan pajaknya. Menurut Mardiasmo (2011:143), untuk Wajib Pajak orang pribadi dihitung sebesar penghasilan neto dikurangi dengan penghasilan tidak kena pajak atau yang lebih sering dikenal dengan PTKP. Sedangkan untuk Wajib Pajak badan dalam negeri dan Bentuk Usaha Tetap (BUT) yang menjadi dasar pengenaan pajak adalah penghasilan kena pajak sebesar penghasilan neto.

Besar kecilnya penghasilan neto sebagai dasar pengenaan pajak yang terutang bergantung pada omzet yang dihasilkan oleh Wajib Pajak dalam 1 (satu) tahun kalender. Dalam Undang-Undang Pajak Penghasilan pasal 14 ayat (2) menyatakan bahwa Wajib Pajak orang pribadi yang melakukan kegiatan usaha atau pekerjaan bebas, boleh menghitung penghasilan neto dengan menggunakan Norma Perhitungan Penghasilan Neto dengan syarat memberitahukan kepada Direktorat Jenderal Pajak (DJP) dalam jangka waktu 3 (tiga) bulan pertama dari tahun pajak yang bersangkutan. Selanjutnya, bagi Wajib Pajak yang tidak memberitahukan pada DJP untuk menggunakan perhitungan neto dengan menggunakan norma perhitungan penghasilan neto dianggap memilih menyelenggarakan pembukuan. Itulah salah satu bentuk keluasan yang diberikan oleh DJP pada Wajib Pajak untuk memberikan kemudahan dalam menentukan besarnya pajak terutang.

Berbagai alternatif telah diberikan oleh DJP untuk memberikan kemudahan bagi Wajib Pajak, dengan kemudahan tersebut secara tidak langsung akan berdampak pada tingkat penerimaan pajak. Mengingat 5 (lima) tahun terakhir ini potensi penerimaan pajak menurun dibandingkan dengan tahun sebelumnya, seperti terlihat pada grafik di bawah ini: 


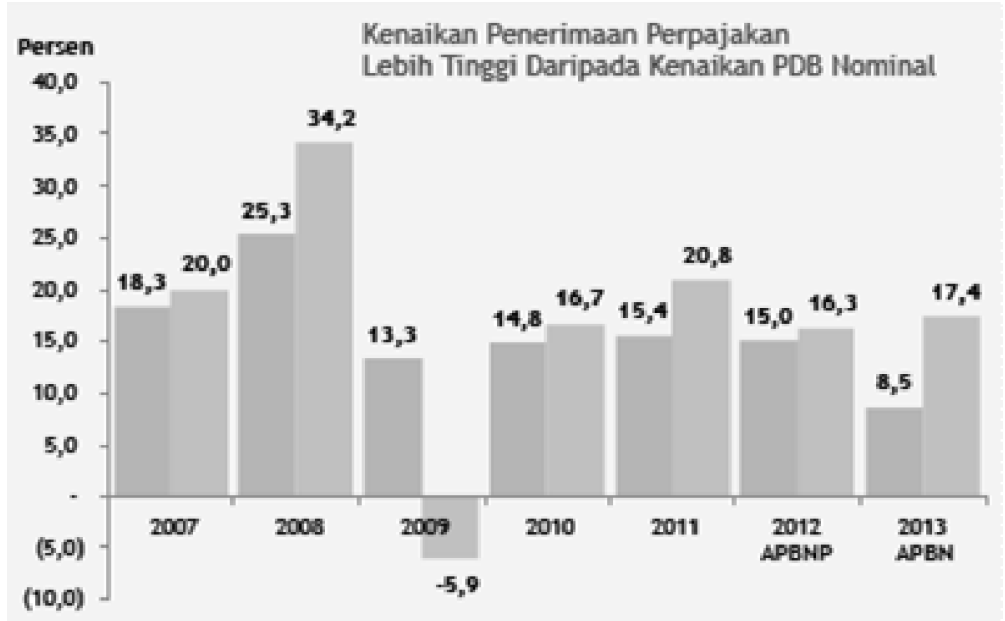

\section{Gambar 1. Pergerakan Penerimaan Pajak}

Sumber:http://www.anggaran.depkeu.go.id/

Salah satu upaya yang dilakukan oleh pemerintah untuk meningkatkan penerimaan pajak yaitu menerbitkan Peraturan Pemerintah (PP) Nomor 46 tahun 2013 tentang Pajak Penghasilan atas Penghasilan dari Usaha yang Diterima atau Diperoleh Wajib Pajak yang memiliki Peredaran Bruto Tertentu. Peraturan ini berlaku bagi Wajib Pajak orang pribadi atau Wajib Pajak badan tidak termasuk bentuk usaha tetap yang menerima penghasilan dari usaha dengan peredaran bruto tidak melebihi Rp.4.800.000.000,00 (empat miliar delapan ratus juta rupiah) dalam 1 (satu) tahun pajak dengan tarif sebesar $1 \%$ bersifat final. Adapun dasar pengenaan pajak yang digunakan untuk menghitung Pajak Penghasilan yang bersifat final ini adalah jumlah peredaran bruto setiap bulan.

Industri songkok merupakan salah satu usaha yang banyak diminati oleh warga masyarakat Kota Gresik, dengan skala usaha yang berbeda-beda. Dengan banyaknya potensi industri songkok ini diharapkan dapat meningkatkan penerimaan pajak sebagai pendapatan Negara dan sudah saatnya mereka sadar akan kewajiban perpajakan sebagai partisipasi dalam pembangunan Negara. Menurut Cak Imin salah satu pemilik industri songkok di Gresik, banyak para UMKM songkok ini yang mempunyai peredaran bruto kurang dari Rp.4.800.000.000 (empat miliar delapan ratus ribu rupiah) dalam 1 (satu) tahun, sehingga sangat memungkinkan untuk memberlakukan peraturan pemerintah terbaru. Oleh karena itu, penulis memilih UMKM songkok sebagai obyek penelitian melihat potensi dalam bidang tersebut sangat memadai yang akan memperlihatkan dampak dari berlakunya peraturan pemerintah nomor 46 tahun 2013 tersebut.

Munculnya peraturan pemerintah ini membuat para pemilik UMKM songkok kesulitan dalam melakukan perhitungan besarnya pajak yang terutang, mengingat 
peraturan pemeritah nomor 46 efektif di pertengahan periode pajak. Di mana, 6 (enam) bulan pertama menggunakan peraturan yang lama sedangkan 6 (enam) bulan kedua menggunakan peraturan pemerintah yang bersifat final ini dan akan menghasilkan perbedaan dalam perhitungan, penyetoran serta pelaporan dibandingkan dengan periode pajak sebelumnya. Selain itu, dengan efektifnya peraturan pemerintah di pertengahan tahun 2013 ini tidak menutup kemungkinan adanya ketidaktahuan masyarakat mengenai berlakunya peraturan tersebut yang bertujuan untuk memberikan kemudahan dalam menentukan besarnya pajak terutang. Sehingga akan memberikan suatu pemikiran positif bagi mereka, dalam hal ini para pelaku UMKM untuk lebih taat melaksanakan kewajiban perpajakannya. Maka masalah pokok yang menjadi fokus penelitian ini adalah bagaimana dampak perlakuan Peraturan Pemerintah No. 46 tahun 2013 atas pajak penghasilan Pada UMKM Industri Songkok di Gresik?

\section{ANALISIS DATA}

\section{Songkok Baitullah}

Songkok Baitullah memang berdiri sejak 2008, akan tetapi pembuatan label sendiri baru di tahun 2012. Meskipun tergolong label baru, akan tetapi kuantitas produksi songkok Baitullah sebanyak 150 kodi per bulan atau 3000 buah songkok. Atas penjualan songkok dengan kuantitas tersebut menghasilkan peredaran bruto kurang dari Rp.4.800.000.00,00 (empat miliar delapan ratus juta rupiah) per tahun.

\section{Analisis Pajak}

Berdasarkan Ketentuan Umum dan Tata Cara Perpajakan Nomor 28 Tahun 2007:

1. Pasal 2 bahwa setiap Wajib Pajak yang telah memenuhi persyaratan subjektif dan objektif sesuai dengan ketentuan perundang-undangan perpajakan wajib mendaftarkan diri pada kantor Direktorat Jenderal Pajak yang wilayah kerjanya meliputi tempat tinggal atau tempat kedudukan Wajib Pajak dan kepadanya diberikan Nomor Pokok Wajib Pajak (NPWP).

2. Pasal 39 menyatakan setiap orang yang dengan sengaja tidak mendaftarkan diri untuk diberikan Nomor Pokok Wajib Pajak, atau menyalahgunakan atau menggunakan tanpa hak NPWP sehingga dapat menimbulkan kerugian pada pendapatan negara dipidana dengan pidana penjara paling singkat 6 (enam) bulan dan paling lama 6 (enam) tahun dan denda paling sedikit 2 (dua) kali jumlah pajak terutang yang tidak atau kurang dibayar dan paling banyak 4 (empat) kali jumlah pajak terutang yang tidak atau kurang dibayar. 


\section{Menghitung}

6 (enam) bulan sebelum diberlakukannya PP 46, berikut perhitungan besarnya pajak penghasilan yang terutang oleh songkok Baitullah 6 (enam) bulan sebelum berlakunya PP 46:

Tabel 1. Perhitungan PPh 6 (enam) Bulan Sebelum Berlakunya PP46

\begin{tabular}{lc}
\hline & $\begin{array}{c}\text { Songkok Baitullah } \\
\text { (Rp) }\end{array}$ \\
\hline Status Pajak & TK/0 \\
Penghasilan / Omzet (6 bulan) & 337.500 .000 \\
(x) \% keuntungan (ditetapkan pemerintah) & $12,5 \%$ \\
Keuntungan bersih usaha & $\mathbf{4 2 . 1 8 7 . 5 0 0}$ \\
(+) Penghasilan lain-lain & - \\
Keuntungan bersih total & $\mathbf{4 2 . 1 8 7 . 5 0 0}$ \\
(-) PTKP & 24.300 .000 \\
Penghasilan Kena Pajak & $\mathbf{1 7 . 8 8 7 . 5 0 0}$ \\
Tarif PPh Terutang & \\
5\% x (0 s/d 50.000.000) & 894.375 \\
15\% x (50.000.000 s/d 250.000.000) & \\
25\% x (250.000.000 s/d 500.000.000) & \\
30\% x (di atas 500.000.000) & - \\
(-) PPh dipotong pihak lain (PPh 21) & - \\
(-) Angsuran PPh yang telah dibayar (PPh 25) & - \\
Total Pengurangan PPh & $\mathbf{8 9 4 . 3 7 5}$ \\
PPh yang masih harus / (kelebihan) bayar & \\
\hline
\end{tabular}

Sumber: Songkok Baitullah, diolah

6 (enam) bulan setelah diberlakukannya PP 46, berikut pajak penghasilan final yang harus dibayar oleh songkok Baitullah per bulan atau masa di tahun 2013:

Tabel 2. Perhitungan PPh Final 6 (enam) bulan Setelah Berlakunya PP46

\begin{tabular}{cllrllr}
\hline No & Bulan & \multicolumn{2}{c}{ Peredaran Bruto } & Tarif & \multicolumn{2}{c}{ PPh Terutang } \\
\hline 7 & Juli & $\mathrm{Rp}$ & 56.250 .000 & & $\mathrm{Rp}$ & 562.500 \\
8 & Agustus & $\mathrm{Rp}$ & 56.250 .000 & & $\mathrm{Rp}$ & 562.500 \\
9 & September & $\mathrm{Rp}$ & 56.250 .000 & & $\mathrm{Rp}$ & 562.500 \\
10 & Oktober & $\mathrm{Rp}$ & 56.250 .000 & $1 \%$ & $\mathrm{Rp}$ & 562.500 \\
11 & November & $\mathrm{Rp}$ & 56.250 .000 & & $\mathrm{Rp}$ & 562.500 \\
12 & Desember & $\mathrm{Rp}$ & 56.250 .000 & & $\mathrm{Rp}$ & 562.500 \\
& TOTAL & Rp & $\mathbf{3 3 7 . 5 0 0 . 0 0 0}$ & & $\mathbf{R p}$ & $\mathbf{3 . 3 7 5 . 0 0 0}$ \\
\hline
\end{tabular}

Sumber: Songkok Baitullah, diolah

Dari perhitungan di atas, total besarnya pajak penghasilan terutang pada tahun 2013 sebesar Rp.4.269.375 (empat juta dua ratus enam puluh sembilan ribu tiga 
ratus tujuh puluh lima rupiah) dengan $\mathrm{PPh}$ final untuk bulan juli sampai desember Rp.3.375.000 dan PPh yang kurang bayar senilai Rp.894.375 yang akan dilaporkan dalam SPT Tahunan Formulir 1770. Maka, dapat dikatakan besarnya PPh terutang menggunakan norma penghasilan neto menghasilkan PPh terutang yang lebih kecil jika dibandingkan dengan menggunakan PP 46 karena masih ada PTKP sebagai pengurang penghasilan kena pajak.

Selain PPh kurang bayar sebesar Rp.894.375 yang akan dilaporkan dalam SPT Tahunan Formulir 1770, masih ada denda yang harus dibayar oleh Wajib Pajak sesuai Undang-Undang No. 28 Tahun 2007 tentang Ketentuan Umum dan Tata Cara Perpajakan pasal 39 dengan denda paling sedikit 2 (dua) kali lipat jumlah pajak yang terutang atau kurang bayar. Maka, total besarnya pajak yang harus disetor oleh Wajib Pajak tahun 2013 dengan rincian sebagai berikut:

Tabel 3. Total PPh Terutang dan Denda yang Harus Disetor

\begin{tabular}{clc}
\hline No & \multicolumn{1}{c}{ Kewajiban Pajak yang Harus Dibayar } & Jumlah \\
\hline 1 & PPh Kurang Bayar & Rp. 894.375 \\
2 & Denda (Sesuai UU KUP Ps 39) & Rp. 1.788 .750 \\
& \multicolumn{1}{c}{ TOTAL } & Rp. 2.683.125 \\
\hline
\end{tabular}

Total pajak yang harus disetor oleh songkok Baitullah adalah sejumlah Rp.2.683.125 (dua juta enam ratus delapan puluh tiga ribu seratus dua puluh lima rupiah) dengan pidana penjara paling singkat selama 6 (enam) bulan.

\section{Songkok Mitra}

Songkok Mitra merupakan industri songkok yang berdiri sejak tahun 2008 dan memiliki omzet kurang Rp.4.800.000.000,00 (empat miliar delapan ratus juta rupiah) dalam 1 (satu) tahun.Dalam mengawasi keuangan usaha songkok ini, pemilik hanya mengandalkan nota penjualan dan tidak melakukan pencatatan sama sekali. Sehingga selama menjalankan usaha ini, beliau tidak membuat pembukuan seperti yang dinyatakan dalam pasal 1 ayat 29 Undang-Undang No. 28 Tahun 2007 tentang Ketentuan Umum dan Tata Cara Perpajakan dengan menyusun laporan keuangan berupa neraca dan laporan laba rugi.

\section{Analisis Pajak}

Berdasarkan Undang-Undang Ketentuan Umum dan Tata Cara Perpajakan Nomor 28 Tahun 2007 pasal 39 bahwa setiap orang yang dengan sengaja tidak menyampaikan Surat Pemberitahuan atau menyampaikan Surat Pemberitahuan dan/atau keterangan yang isinya tidak benar atau tidak lengkap sehingga dapat menimbulkan kerugian pada pendapatan negara dipidana dengan pidana penjara paling singkat 6 (enam) bulan dan paling lama 6 (enam) tahun dan denda paling 
sedikit 2 (dua) kali jumlah pajak terutang yang tidak atau kurang dibayar dan paling banyak 4 (empat) kali jumlah pajak terutang yang tidak atau kurang dibayar.

\section{Menghitung}

6 (enam) bulan sebelum diberlakukannya PP 46, berikut perhitungan pajak penghasilan yang terutang sebelum berlakunya PP 46 untuk bulan januari sampai juni 2013 dengan menggunakan norma perhitungan neto:

Tabel 4. Perhitungan PPh 6 (enam) Bulan Sebelum Berlakunya PP 46

\begin{tabular}{lc}
\hline & Songkok Mitra (Rp) \\
\hline Status Pajak & K/3 \\
Penghasilan / Omzet (6 bulan) & 456.895 .000 \\
(x) \% keuntungan (ditetapkan pemerintah) & $12,5 \%$ \\
Keuntungan bersih usaha & $\mathbf{5 7 . 1 1 1 . 8 7 5}$ \\
(+) Penghasilan lain-lain & - \\
Keuntungan bersih total & $\mathbf{5 7 . 1 1 1 . 8 7 5}$ \\
(-) PTKP & 32.400 .000 \\
Penghasilan Kena Pajak & $\mathbf{2 4 . 7 1 1 . 8 7 5}$ \\
\hline
\end{tabular}

Tabel 4. Lanjutan

\begin{tabular}{lc}
\hline & Songkok Mitra (Rp) \\
\hline Tarif PPh Terutang & \\
$5 \% \times(0 \mathrm{~s} / \mathrm{d} 50.000 .000)$ & 1.235 .550 \\
$15 \% \times(50.000 .000 \mathrm{~s} / \mathrm{d} 250.000 .000)$ & \\
$25 \% \times(250.000 .000 \mathrm{~s} / \mathrm{d} 500.000 .000)$ & \\
$30 \% \times($ di atas 500.000.000) & - \\
(-) PPh dipotong pihak lain (PPh 21) & - \\
(-) Angsuran PPh yang telah dibayar (PPh 25) & - \\
Total Pengurangan PPh & $\mathbf{1 . 2 3 5 . 5 5 0}$ \\
PPh yang masih harus / (kelebihan) bayar &
\end{tabular}

Sumber : Songkok Mitra, diolah

6 (enam) bulan setelah diberlakukannya PP 46, berikut jumlah pajak penghasilan final yang harus dibayar per masa oleh songkok Mitra untuk bulan juli-desember 2013: 
Tabel 5. Perhitungan PPh 6 (enam) bulan Setelah Berlakunya PP46

\begin{tabular}{lllrrrr}
\hline No & Tanggal / Bulan & \multicolumn{3}{c}{ Peredaran Bruto } & $\begin{array}{c}\text { Tarif PPh } \\
\text { Final }\end{array}$ & \multicolumn{2}{c}{ PPh Terutang } \\
\hline 1 & Juli & $\mathrm{Rp}$ & 251.857 .500 & & $\mathrm{Rp}$ & 2.518 .575 \\
2 & Agustus & $\mathrm{Rp}$ & 24.800 .000 & & $\mathrm{Rp}$ & 248.000 \\
3 & September & $\mathrm{Rp}$ & 78.350 .000 & & $\mathrm{Rp}$ & 783.500 \\
4 & Oktober & $\mathrm{Rp}$ & 86.864 .000 & & $\mathrm{Rp}$ & 868.640 \\
5 & November & $\mathrm{Rp}$ & 107.000 .000 & $1 \%$ & $\mathrm{Rp}$ & 1.070 .000 \\
6 & Desember & $\mathrm{Rp}$ & 85.600 .000 & & $\mathrm{Rp}$ & 856.000 \\
& TOTAL & $\mathrm{Rp}$ & 634.471 .500 & & $\mathrm{Rp}$ & 6.344 .715 \\
\hline
\end{tabular}

Sumber: Songkok Mitra, diolah

Besarnya pajak penghasilan yang terutang untuk tahun 2013 dengan total Rp.7.580.265 (tujuh juta lima ratus delapan puluh ribu dua ratus enam puluh lima rupiah) dengan rincian untuk PPh finalnya sebesar Rp. 6.344.715 dan PPh kurang bayar Rp. 1.235.550 yang akan dilaporkan secara dalam SPT Tahunan Wajib pajak orang pribadi Formulir 1770. Sedangkan untuk rincian total besarnya pajak yang harus disetor oleh songkok Mitra adalah:

Tabel 6. Total PPh Terutang dan Denda yang Harus Disetor

\begin{tabular}{clc}
\hline No & \multicolumn{1}{c}{ Kewajiban Pajak yang Harus Dibayar } & Jumlah \\
\hline 1 & PPh Kurang Bayar & Rp. 1.235 .550 \\
2 & Denda (Sesuai UU KUP Ps 39) & Rp. 2.471 .100 \\
& $\quad$ TOTAl & Rp. 3.706.650 \\
\hline
\end{tabular}

Selain besarnya pajak yang harus disetor, ada pidana paling singkat 6 (enam) bulan yang harus dijalani karena dengan tidak menyampaikan SPT Tahunan. Berbeda halnya mengenai besarnya peredaran bruto sampai tahun 2013 yang dijadikan sebagai ukuran dikukuhkannya seorang pengusaha sebagai Pengusaha Kena Pajak atau bisa disebut sebagai PKP bagi pengusaha yang memiliki peredaran bruto minimal Rp.600.000.000 (enam ratus juta rupiah) per tahun, sehingga berkewajiban melapor untuk dikukuhkannya sebagai PKP. Namun, songkok Mitra mempunyai omzet lebih dari Rp.600.000.000 per tahun dan tidak melaporkan dirinya untuk dikukuhkan sebagai PKP, maka terhadap pengusaha yang telah memenuhi syarat sebagai PKP tetapi tidak melaporkan usahanya untuk dikukuhkan sebagai PKP akan dikukuhkan sebagai PKP secara jabatan dan dikenakan sanksi perpajakan seperti dalam pasal 39 Undang-Undang No. 28 Tahun 2007 tentang Ketentuan Umum dan Tata Cara Perpajakan. 


\section{Songkok Ulama}

Songkok Ulama merupakan industri songkok yang berdiri sejak tahun 2005 serta mempunyai omzet kurang dari Rp. 4.800.000.000,00 (empat miliar delapan ratus juta rupiah), akan tetapi dalam pembuatan label sendiri seperti songkok Baitullah masih tergolong baru sehingga beliau sangat memperhatikan kuantitas produksi. Seperti industri songkok lainnya, dalam mengawasi keuangan usaha songkok Ulama ini tidak ada pencatatan maupun pembukuan dengan menyusun laporan keuangan berupa neraca dan laporan laba rugi seperti yang diatur dalam Pasal 1 ayat 29 Undang-Undang No. 28 Tahun 2007 tentang Ketentuan Umum dan Tata Cara Perpajakan.

\section{Analisis Pajak}

6 (enam) bulan sebelum diberlakukannya PP 46, berikut hasil perhitungan pajak penghasilan untuk peredaran bruto bulan januari-juni tahun 2013 dengan menggunakan norma penghasilan neto:

Tabel 7. Perhitungan PPh 6 (enam) Bulan Sebelum Berlakunya PP46

\begin{tabular}{lc}
\hline & Songkok Ulama (Rp) \\
Status Pajak & K/3 \\
\hline Penghasilan / Omzet (6 bulan) & 132.516 .000 \\
(x) \% keuntungan (ditetapkan pemerintah) & $12,5 \%$ \\
Keuntungan bersih usaha & $\mathbf{1 6 . 5 6 4 . 5 0 0}$ \\
(+) Penghasilan lain-lain & - \\
Keuntungan bersih total & $\mathbf{1 6 . 5 6 4 . 5 0 0}$ \\
(-) PTKP & 32.400 .000 \\
Penghasilan Kena Pajak & $\mathbf{( 1 5 . 8 3 5 . 5 0 0 )}$ \\
Tarif PPh Terutang & \\
$5 \%$ x (0 s/d 50.000.000) & \\
15\% x (50.000.000 s/d 250.000.000) & \\
25\% x (250.000.000 s/d 500.000.000) & \\
30\% x (di atas 500.000.000) & \\
(-) PPh dipotong pihak lain (PPh 21) & - \\
(-) Angsuran PPh yang telah dibayar (PPh 25) & 60.000 \\
Total Pengurangan PPh & $\mathbf{6 0 . 0 0 0}$ \\
PPh yang masih harus / (kelebihan) bayar & $\mathbf{( 6 0 . 0 0 0 )}$ \\
\hline
\end{tabular}

Sumber: Songkok Ulama, diolah

6 (enam) bulan setelah diberlakukannya PP 46, berikut pajak penghasilan final yang harus dibayar oleh songkok Ulama selama masa juli sampai Desember 2013: 
Tabel 8. Perhitungan PPh Final 6 (enam) Bulan Setelah Berlakunya PP46

\begin{tabular}{|c|c|c|c|c|c|c|}
\hline \multirow{2}{*}{$\begin{array}{l}\text { No } \\
1\end{array}$} & \multirow{2}{*}{$\begin{array}{l}\text { Tang gal / Bulan } \\
\text { Juli }\end{array}$} & \multicolumn{2}{|c|}{ Peredaran Bruto } & \multirow[t]{2}{*}{$\begin{array}{c}\text { Tarif PPh } \\
\text { Final } \\
\end{array}$} & \multicolumn{2}{|c|}{ PPh Terutang } \\
\hline & & $\mathrm{Rp}$ & 32.200 .000 & & $\mathrm{Rp}$ & 322.000 \\
\hline 2 & Agustus & Rp & 35.750 .000 & & $\mathrm{Rp}$ & 357.500 \\
\hline 3 & September & $\mathrm{Rp}$ & 21.550 .000 & & $\mathrm{Rp}$ & 215.500 \\
\hline 4 & Oktober & $\mathrm{Rp}$ & 19.950 .000 & $1 \%$ & $\mathrm{Rp}$ & 199.500 \\
\hline 5 & November & $\mathrm{Rp}$ & 17.900 .000 & & $\mathrm{Rp}$ & 179.000 \\
\hline \multirow[t]{2}{*}{6} & Desember & $\mathrm{Rp}$ & 16.150 .000 & & $\mathrm{Rp}$ & 161.500 \\
\hline & Total & $\mathrm{Rp}$ & 143.500 .000 & & $\mathrm{Rp}$ & 1.435 .000 \\
\hline
\end{tabular}

Sumber: Songkok Ulama, diolah

Total besarnya pajak penghasilan yang harus dibayar oleh songkok Mitra yaitu sebesar Rp.1.435.000 (satu juta empat ratus tiga puluh lima ribu rupiah) untuk PPh final, sedangkan untuk pajak penghasilan sebelum diberlakukannya PP 46 telah mengalami lebih bayar Rp.60.000 (enam puluh ribu) atas kredit pajak yang dibayar oleh songkok ulama karena keuntungan yang diperoleh oleh Wajib Pajak berdasarkan norma yang ditetapkan oleh pemerintah lebih besar dibandingkan PTKP sehingga tidak ada pajak yang harus dibayar selain $\mathrm{PPh}$ final ynag disetorkan per masa.

\section{PEMBAHASAN}

Penyusunan laporan laporan keuangan suatu entitas akan bermanfaat bagi pihak yang berkepentingan atas informasi-informasi yang ada dalam laporan tersebut. Seperti halnya laporan laba rugi, dengan laporan tersebut pemilik akan mengetahui besarnya laba yang diperoleh dalam menjalankan usaha tersebut atas pendapatan yang diperoleh dengan beban-beban yang dikeluarkan. Selain itu, dengan laporan tersebut dapat digunakan sebagai alat untuk menghitung besarnya pajak penghasilan $(\mathrm{PPh})$ yang terutang dengan menggunakan pembukuan. Perhitungan $\mathrm{PPh}$ terutang menggunakan pembukuan akan lebih memperlihatkan kondisi yang sebenarnya dalam menjalankan usaha. Namun, diperlukan pengetahuan serta kemampuan yang ekstra bagi UMKM untuk dapat menyusun laporan keuangan. Berdasarkan analisis laporan keuangan yang dilakukan yaitu laporan laba rugi 3 industri songkok tersebut, rata-rata menghasilkan laba yang berada dikisaran $6 \%$ dari peredaran bruto yang diperoleh selama tahun 2013.

Berbeda halnya dengan Peraturan Pemerintah No. 46 Tahun 2013, di mana peredaran bruto sebagai dasar pengenaan pajak dengan tanpa menyusun laporan keuangan bisa menghitung besarnya PPh terutang karena bukan laba yang dijadikan sebagai dasar pengenaannya. Adapun dampak dari berlakunya peraturan tersebut menghasilkan pajak penghasilan yang terutang lebih besar, selain itu munculnya 
dari peraturan yang berada di pertengahan tahun 2013 sempat memberikan kesulitan atau keraguan bagi Wajib Pajak dalam melaporkan pajaknya. Berlakunya peraturan tersebut juga banyak tidak diketahui oleh industri songkok baik dari segi adanya peraturan itu sendiri maupun mekanisme perhitungan pajaknya.

Atas analisis perbandingan yang dilakukan, dapat dilihat secara jelas bahwa perhitungan besarnya pajak penghasilan yang terutang akan lebih kecil jika menggunakan pembukuan karena setiap beban yang dikeluarkan bisa menjadi pengurang penghasilan yang akan dijadikan sebagai dasar pengenaan pajak. selain itu, kelebihan dengan menggunakan pembukuan yaitu adanya PTKP yang bisa memperkecil penghasilan kena pajak. Akan tetapi, dengan menggunakan pembukuan akan membutuhkan kemampuan untuk menyusun pembukuan berupa laporan keuangan secara terperinci. Undang-Undang No. 28 tentang Ketentuan Umum dan Tata Cara Perpajakan pasal 28 menyatakan bahwa pembukuan sekurang-kurangnya terdiri atas catatan mengenai harta, kewajiban, modal, penghasilan dan beban, serta penjualan dan pembelian sehingga dapat dihitung besarnya pajak yang terutang.

Untuk perhitungan pajak penghasilan dengan menggunakan norma penghasilan neto akan lebih sederhana daripada dengan menggunakan pembukuan, pertimbangan lain menggunakan metode ini yaitu adanya PTKP sebagai pengurang penghasilan kena pajak. Di mana Wajib Pajak tidak harus membuat laporan keuangan melainkan kisaran besarnya keuntungan yang diperoleh Wajib Pajak telah ditentukan oleh pemerintah yaitu sebesar $12,5 \%$. Jika dibandingkan dengan menggunakan pembukuan, besarnya norma yang telah ditetapkan oleh pemerintah untuk industri tekstil belum bisa mencerminkan keuntungan yang sebenarnya. Hal tersebut terlihat dari perbedaan yang jauh akan besarnya pajak penghasilan dengan menggunakan pembukuan jika dibandingkan dengan menggunakan norma penghasilan neto. Berdasarkan Undang-Undang No.36 tahun 2008 tentang pajak penghasilan menyatakan Wajib Pajak orang pribadi yang melakukan kegiatan usaha yang peredaran brutonya dalam 1 (satu) tahun kurang dari Rp.4.800.000.000,00 (empat miliar delapan ratus juta rupiah) boleh menghitung penghasilan neto dengan menggunakan Norma Perhitungan Penghasilan Neto dengan syarat memberitahukan kepada Direktur Jenderal Pajak dalam jangka waktu 3 (tiga) bulan pertama dari tahun pajak yang bersangkutan.

Berbeda dengan Peraturan Pemerintah No. 46 tahun 2013 ini, diberlakukannya peraturan tersebut untuk memberi kemudahan bagi Wajib Pajak dalam menentukan besarnya pajak yang terutang. Peraturan ini bersifat final dengan dasar pengenaan pajak peredaran bruto, besarnya tarif $\mathrm{PPh}$ final ini adalah $1 \%$ (satu persen). Dilihat dari segi mekanisme perhitungan memang mudah, akan tetapi jika dilihat besar kecilnya pajak penghasilan yang terutang akan terlihat paling besar jika dibandingkan dengan menggunakan pembukuan dan norma penghasilan neto.

Dari penjelasan di atas, dapat dikatakan bahwa akan lebih menguntungkan bagi Wajib Pajak sebagai salah satu upaya untuk melakukan perencanaan pajak 
dengan penghematan pajak jika menghitung pajak penghasilan yang terutang dengan menggunakan pembukuan karena menghasilkan jumlah PPh terutang yang paling kecil. Apabila Wajib Pajak merasa kesulitan dalam membuat pembukuan, Wajib Pajak dapat menggunakan alternatif kedua yaitu perhitungan pajak penghasilan dengan menggunakan norma penghasilan neto karena terlihat dengan metode tersebut menghasilkan PPh terutang yang lebih kecil dibandingkan dengan menggunakan peraturan pemerintah terbaru. Jika Wajib Pajak masih merasa kesulitan dengan menggunakan norma penghasilan neto, Wajib pajak dapat menggunakan peraturan pemerintah sebagai alternatif perhitungan PPh terutang. Pada dasarnya 3 (tiga) metode perhitungan pajak penghasilan tersebut diberikan oleh pemerintah dalam hal ini Direktur Jenderal Pajak (DJP) untuk memberikan kemudahan bagi para Wajib Pajak dalam menentukan besarnya PPh yang terutang, sehingga menumbuhkan kesadaran bagi para Wajib Pajak untuk sepenuhnya memenuhi kewajiban perpajakannya sebagai bentuk partisipasi rakyat kepada Negara.

Berbagai kemudahan telah diberikan oleh pemerintah dalam hal ini Direktorat Jenderal Pajak (DJP) baik dari kewajiban menghitung, menyetor dan melapor. Dari segi perhitungan, telah dijelaskan sebelumnya bahwa pemerintah telah memberikan keluasan bagi Wajib Pajak untuk menghitung sendiri besarnya pajak yang terutang dengan menggunakan pembukuan atau norma penghasilan neto atau peraturan pemerintah yang bersifat final. Dari segi penyetoran, atas berlakunya PP 46 pemerintah mengeluarkan Peraturan Direktorat Jenderal Pajak Nomor PER37/PJ/2013 yang berisi mengenai atas pajak penghasilan yang bersifat final tersebut dapat disetorkan melalui Ajungan Tunai Mandiri (ATM) dengan memasukkan NPWP, Masa Pajak dan jumlah nominal Pajak Penghasilan yang akan dibayar dengan BPN (Bukti Penerimaan Negara) sebagai sarana administrasi lain yang kedudukannya disamakan Surat Setoran Pajak. Dari segi pelaporan, pemerintah memberikan aplikasi e-Filing yaitu sistem pelaporan SPT yang menggunakan sarana internet tanpa melalui pihak lain dan tanpa beban apapun melalui efiling.pajak.go.id yang dibuat oleh Direktorat Jenderal Pajak (DJP) untuk memberikan kemudahan bagi Wajib Pajak dalam pengisian dan penyerahan SPT.

\section{Kajian Perspektif Islam}

Ada alasan dimana keharusan kaum muslimin untuk menunaikan kewajiban pajak yang ditetapkan negara, dalam Al-Qur'an Allah SWT berfirman dalam Surat An-Nisa' ayat 59:

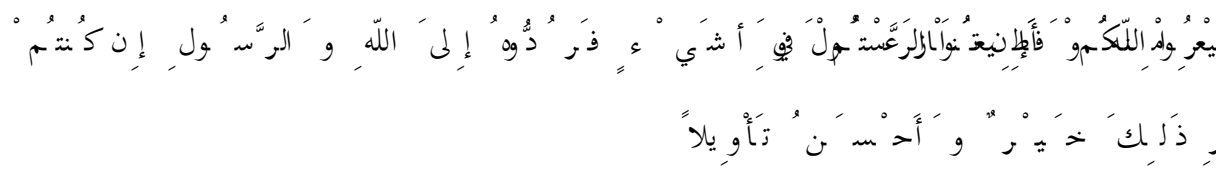


Artinya:

"Hai orang-orang yang beriman, taatilah Allah dan taatilah Rasul-Nya dan ulil amri di antara kamu. Kemudian jika kamu berlainan pendapat tentang sesuatu, maka kembalikanlah ia kepada Allah (Al-Qur'an) dan Rasulullah saw (sunnahnya), jika kamu benar-benar beriman kepada Allah dan hari kemudian. Yang demikian itu lebih utama (bagimu) dan lebih baik akibatnya."

Dari ayat diatas, terlihat sangat jelas bahwa Allah SWT menyeru pada umat manusia untuk taat kepada ulil amri atau bisa disebut pemimpin yaitu pemerintah selain pada Allah SWT dan Rasul-Nya. Seperti halnya mengenai kewajiban perpajakan ini, dimana pemerintah membuat undang-undang untuk dipatuhi atau ditaati rakyat sebagai sumber pendapatan Negara yang akan dikelola dan dialokasikan oleh pemerintah dengan sebaik-baiknya untuk belanja keperluan Negara Indonesia.

Seperti Allah SWT memberikan petunjuk dan perintah-Nya yang terutang dalam Al-Qur'an, sedangkan Rasul-Nya yang bersabda dalam sunnahnya begitu juga dengan ulil amri yang menyangkut Negara tertuang dalam Undang-Undang yang mengatur segala hal yang bersangkutan dengan permasalahan yang ada diantaranya mengenai kewajiban perpajakan oleh rakyat kepada Negaranya.

Berdasarkan hasil penelitian yang dilakukan, ketika Wajib Pajak tidak melakukan kewajiban perpajakannya dengan baik sesuai Undang-Undang yang berlaku maka ada hukuman yang diatur baik dengan materi (uang) atau denda maupun pidana. Di samping itu, telah dijelaskan sebelumnya dalam surat An-Nisa' ayat 59 bahwa Allah SWT telah memerintah umat manusia untuk taat juga kepada ulil amridalam hal ini pemerintah yang terutang dalam Undang-Undang untuk dijalankan dan ditaati sebagaimana mestinya, dengan begitu jika umat manusia tidak menjalankannya maka selain hukuman yang bersifat materi maka mendapat dosa bagi yang tidak menjalankannya.

\section{SIMPULAN}

Dalam penelitian ini, penulis melakukan 3 (tiga) analisis yaitu:

1. Analisis Laporan Keuangan, dapat dikatakan bahwa dengan membuat laporan keuangan khususnya laporan laba rugi, akan memberikan informasi-informasi bagi pemilik mengenai besarnya keuntungan yang diperoleh selama tahun 2013 atas pendapatan yang diperoleh dengan beban-beban yang telah dikeluarkan. Selain itu, dengan menyusun laporan keuangan dapat dijadikan dasar sebagai pengambilan keputusan entitas dan perhitungan pajak penghasilan terutang dengan pembukuan.

2. Analisis Pajak, pada analisis ini peneliti memberikan ilustrasi mengenai perhitungan, penyetoran serta pelaporan pajak penghasilan yang terutang di tahun 2013, mengingat adanya kesulitan dalam melakukan kewajiban perpajakan 
tersebut di tahun 2013 dikarenakan efektifnya Peraturan Pemerintah No. 46 di pertengahan periode.

3. Analisis Perbandingan, atas perbandingan yang telah dilakukan atas perhitungan besarnya pajak penghasilan yang terutang dengan menggunakan pembukuan, norma perhitungan penghasilan neto dan PP 46 Tahun 2013.

Dari penelitian dan analisis yang dilakukan, dapat disimpulkan bahwa dampak diberlakukannya peraturan pemerintah No.46 tahun 2013 ini yang berada di pertengahan tahun selain memberikan kesulitan bagi Wajib Pajak dalam hal perhitungan, penyetoran dan pelaporan juga belum banyak diketahui oleh industri songkok baik dari segi berlakunya peraturan pemerintah itu sendiri maupun segi mekanisme perhitungannya. Adapun dampak lain yaitu perhitungan pajak penghasilan menggunakan Peraturan Pemerintah No. 46 Tahun 2013 tentang Pajak Penghasilan atas Penghasilan dari Usaha yang Diterima atau Diperoleh Wajib Pajak yang Memiliki Peredaran Bruto Tertentu telah menghasilkan pajak penghasilan terutang yang paling tinggi jika dibandingkan dengan menggunakan pembukuan dan norma perhitungan penghasilan neto.

Begitu juga PPh terutang menggunakan pembukuan menghasilkan pajak yang lebih kecil dibandingkan dengan menggunakan perhitungan penghasilan neto, ini menunjukkan bahwa besarnya tingkat keuntungan dengan norma yang telah ditetapkan oleh pemerintah belum bisa mencerminkan keadaan industri songkok yang sebenarnya. Hal ini terlihat dari besarnya omzet yang diperoleh selama tahun 2013 oleh industri songkok Baitullah sebesar Rp. 675.000.000 dengan PPh terutang menggunakan pembukuan senilai Rp. 676.625, sedangkan menggunakan norma perhitungan Rp.4.011.250 dan jika menggunakan PP 46 sebesar Rp. 6.750.000 atau 9 kali lipat dari pembukuan. Untuk songkok Mitra besarnya peredaran bruto yang diperoleh Rp. 1.091.366.500 dengan PPh terutang menggunakan pembukuan sebesar Rp.2.154.575, sedangkan dengan menggunakan norma Rp. 10.603.122 dan PP 46 Rp. 10.913.665 mencapai 5 atau 7 kali lipat dari PPh terutang dengan menggunakan pembukuan. Sedangkan untuk songkok Ulama' besarnya omzet yang diperoleh Rp. 276.016.000 per tahun dengan besarnya pajak penghasilan yang terutang menggunakan norma perhitungan Rp. 105.100 dan PP 46 sebesar Rp. 2.760.260.

\section{DAFTAR PUSTAKA}

Al-Qur'an Karim dan Terjemahan. http://www.anggaran.depkeu.go.id/, diakses 30 Desember 2013. http://www.pajak.go.id/, diakses 15 Desember 2013. http://www.pajakonline.com, diakses 15 Desember 2013

Kholis, Nur. 2010. Pajak dalam Perspektif Islam dan Aplikasinya di Indonesia. http:// nurkholis77.staff.uii.ac.id/wakaf-dan-upaya-memberdayakan-potensinya-secaraproduktif-di-indonesia/, diakses 29 Desember 2013. 
Mardiasmo. 2011. Perpajakan Edisi Revisi. Yogyakarta: CV Andi.

Peraturan Direktur Jenderal Pajak Nomor Per-37/PJ/2013 tentang Tata Cara Penyetoran Pajak Penghasilan atas Penghasilan Dari Usaha yang Diterima atau Diperoleh Wajib Pajak yang Memiliki Peredaran Bruto Tertentu Melalui Ajungan Tunai Mandiri (ATM)

Peraturan Pemerintah Nomor 46 Tahun 2013 tentang Pajak Penghasilan atas Penghasilan Dari Usaha yang Diterima atau Diperoleh Wajib Pajak yang Memiliki Peredaran Bruto Tertentu.

Priyantarno, M. 2013. PP 46/2013 Pisau yang Bermata Dua. http://www.pajak.go.id/content/article/pp-462013-pisau-yang-bermata-dua, diakses 07 Desember 2013.

Pusparini, I.A., dkk. 2013. Implementasi Tax Planning dalam Upaya Penghematan Pajak Penghasilan (PPh) Badan, Jurnal. Fakultas Ilmu Administrasi Universitas Brawijaya, Malang.

Tambunan, R. 2013. Ketentuan Terbaru Pajak Penghasilan Atas UMKM: Sederhana Tapi Tidak Adil. http://www.ortax.org/ortax/?mod=issue \&page $=$ show\&id=51, diakses 09 Desember 2013.

Tim FE UIN MALIKI. 2012. Buku Pedoman Penulisan Skripsi, Malang.

Undang-Undang Nomor 28 Tahun 2007 tentang Perubahan Ketiga atas Undang-Undang Nomor 6 Tahun 1983 tentang Kententuan Umum dan Tata Cara Perpajakan (KUP).

Undang-Undang Nomor 36 Tahun 2008 tentang Perubahan Keempat Atas Undang-Undang Nomor 7 Tahun 1983 Tentang Pajak Penghasilan.

Waluyo. 2010. Perpajakan Indonesia Edisi 9. Jakarta: Salemba Empat.

Waluyo. 2012. Akuntansi Pajak Edisi 4. Jakarta: Salemba Empat.

Zain, M. 2007. Manajemen Perpajakan Edisi 3. Jakarta: Salemba Empat. 